\title{
Supervisi Pendidiksan Pada Masa Pandemi Covid-19 Di Madrasah Tsanawiyah Darul Ulum
}

\author{
1.Musonip Saputro, 2.M Fathoni, 3.Minnah El Widdah, 4.Suryawahyuni Latief \\ 1\&2 Pascasarjana UIN Sulthan Thaha Saifuddin Jambi \\ email: musonips7@gmail.ac.id dan myfathoni@gmail.com \\ 3 Manajemen Pendidikan UIN Sulthan Thaha Saifuddin Jambi \\ Email: elwiddah01@uinjambi.ac.id \\ 4 Universitas Nurdin Hamzah Jambi \\ Email: ninek_yuni@yahoo.com
}

\begin{abstract}
The head of the madrasa must be able to carry out supervision activities to improve teacher performance. Supervision will help identify deficiencies in the teacher's learning process so far. Then look for joint solutions to improve learning activities in the classroom. This study reveals the performance of Darul Ulum Private MTS Madrasah teachers during the Covid-19 pandemic. The results of this study are: 1) Supervision is carried out in several stages, namely: planning, implementing and tracking. Supervision is carried out by the head of the madrasa and assisted by the teacher council. Matters that are subject to supervision include: administrative and academic supervision. Administrative supervision is carried out before the implementation of distance learning. Academic supervision is carried out by means of tutors taking virtual classes or online classes; 2) Obstacles in the implementation of supervision, namely the schedule of solid activities, computer literacy is still low, madrasa facilities supporting online learning are not enough, 3) Follow-up for some teachers who are not proficient in teaching methods is through the Zenius application to make it easier for teachers to take part in online training. In addition, madrasas also provide the facilities needed for these teachers to carry out distance learning in the form of providing adequate computers and equipment
\end{abstract}

\section{Keywords: Education Supervision, School Supervision}

\section{Pendahuluan}

Pendidikan di Indonesia masih tertinggal jika dibandingkan dengan negara lain. Hal ini terjadi karena beberapa permasalahan lama dan permasalahan baru yang muncul seiring dengan penyesuaian kebutuhan masyarakat. Apalagi pada saat ini, pandemi COVID -19 memberikan dampak pada setiap bidang kehidupan tidak terkecuali bidang pendidikan. Semua negara terdampak telah berupaya membuat kebijakan terbaiknya dalam menjaga kelanggengan layanan pendidikan. Selain merubah kebiasaan sehari-hari, kemunculan virus ini merubah sistem pembelajaran yang tentu saja menjadi tantangan bagi setiap sekolah untuk tidak gentar dan berusaha melakukan yang terbaik agar para Responden dapat mendapatkan haknya untuk tetap belajar (Raluca, 2020, p.15).

Berbagai kebijakan dan pemberlakuan protokol kesehatan dilakukan untuk memutus mata rantai penyebaran covid19. Lockdown di negara-negara yang terdampak 
covid-19 berimbas pada dunia kerja yaitu WFH (Work from Home) bahkan merumahkan para pegawainya. Di dunia pendidikan, kebijakan SFH atau School from Home pun diterapkan untuk menekan penularan covid-19. Sekolah-sekolah ditutup dan pembelajaran daring-pun dilakukan. Hal ini tentu tidak mudah dilaksanakan oleh semua siswa. Dibutuhkan kerjasama orang tua dan guru untuk membimbing siswa. Berbagai masalah muncul mulai dari orang tua yang kurang memahami pelajaran sekolah karena latar belakang pendidikan sebelumnya, belum melek teknologi, bahkan membengkaknya biaya bulanan karena harus membeli kuota namun juga tetap membayar uang sekolah.

Dari sisi hasil pembelajarannya, siswa tentu tidak semudah menangkap pembelajaran secara langsung seperti manakala berada di sekolah. Diperlukan penguasaan alat pembelajaran, materi pembelajaran dan komunikasi yang baik dalam menyampaikan pembelajaran melalui daring. Guru perlu memiliki kompetensi-kompetensi tertentu yang mendukung keberhasilan pembelajaran siswa pada masa pandemi ini. Tulisan ini akan membahas lebih lanjut kompetensi sumber daya manusia yang diperlukan, dalam hal ini guru sebagai pendidik, dalam tugas dan tanggung jawabnya menjalankan profesinya di tengah pandemi ini.

Berbagai upaya dilakukan untuk membantu kegiatan di lembaga pendidikan tetap berjalan degan baik. Dari berbagai upaya yang dapat dilakukan untuk memperbaiki kualitas pendidikan, diantaranya adalah dengan adanya supervisi pendidikan. Program supervisi di sekolah memberikan peluang kepada para guru untuk memperbaiki kualitas diri terutama yang berkaitan dengan proses pembelajaran. Supervisi pendidikan merupakan elemen krusial dalam pendidikan yang akan bisa mendorong perbaikan demi mewujudkan tujuan dan cita-cita pendidikan itu sendiri. Cita-cita yang diimpikan oleh seluruh elemen, baik negara, lembaga pendidikan, siswa, wali murid, maupun masyarakat secara umum. Perbaikan hasil dari supervisi tersebut dapat dilakukan secara individual maupun berkelompok.

Sasaran utama supervisi adalah para guru yang mempunyai peran sangat vital dalam membentuk karakter generasi penerus bangsa. Guru memiliki potensi untuk berkreasi dan meningkatkan kinerjanya. Namun demikian seringkali banyak faktor yang menghambat mereka dalam mengembangkan berbagai potensinya secara optimal, baik itu berupa kemampuan guru itu sendiri dalam proses belajar mengajar, maupun sarana dan prasarana pendidikan yang tersedia. Mengingat hal tersebut sangat dirasakan perlunya supervisiyang berkesinambungan dengan program yang terarah dan sistematis terhadap 
guru. Program supervisi guru tersebut lazim disebut supervisi yang merupakan suatu rangkaian penting dalam manejemen pendidikan (Ajasan, 2016, p 23).

Adapun fungsi utama dari supervisi pendidikan adalah fungsi dasar dari supervisi adalah untuk memperbaiki situasi belajar mengajar di sekolah agar lebih baik. Supervisi terhadap proses belajar mengajar, merupakan salah satu bentuk aktivitas yang direncanakan untuk membantu para guru dalam melakukan pekerjaan mereka secara efektif (Fathurrahman, 2018, p.26).

Pengawasan dan pengendalian merupakan tindakan pencegahan agar guru tidak melakukan penyimpangan dan lebih berhati-hati dalam melaksanakan pekerjaannya sebagai pendidik (Fathurrahman, 2018, p.28). Dari hasil observasi awal terhadap kepala madrasah pada MTs Darul Ulum Rasau menemukan banyaknya kendala supervisi. Oleh sebab itu, supervisi belum bisa terlaksanana sebagaimana mestinya serta belum mampu memberikan peningkatan kegiatan proses belajar mengajar. Fakta di lapangan masih ditemukan beberapa guru yang mengajar kekurangan acuan rencana pelaksanaan pembelajaran yang jelas selain RPP yang sudah dibuat. Hal ini dapat dimaklumi karena proses pelaksanaan pembelajaran secara online tentunya menyisakan banyak masalah dan kendala yang dialami baik oleh guru maupun peserta didik.

\section{Metodelogi Penelitian}

Penelitian ini menggunakan metode deskriptif dengan pendekatan kualitatif yang bersifat fenomenologis yaitu menyelidiki suatu fenomena sosial atau masalah manusia. Metode penelitian kualitatif adalah metode penelitian yang digunakan untuk meneliti pada kondisi obyek yang alamiah di mana peneliti adalah sebagai instrumen kunci, teknik pengumpulan data dilakukan secara trianggulasi (gabungan), analisis data bersifat induktif dan hasil penelitian kualitatif lebih menekankan makna dari pada generalisasi (Sugiyono, 2011, p. 20).

Penelitian kualitatif merupakan suatu pendekatan dalam melakukan penelitian yang berorientasi pada fenomena atau gejala yang bersifat alami. Karena orientasinya demikian, sifatnya mendasar dan naturalistis atau kealamian. Pendekatan kualitatif menjadi populer, terutama dalam bidang psikologi sosial, sosiologi, dan pendidikan, setelah para ahli merasakan banyaknya kelemahan dalam penelitian yang dilakukan di laboratorium dengan menggunakan eksperimen (Mahmud, 2011, p.33). 
Dalam pendekatan fenomenologi peneliti berusaha memahami arti dari berbagai peristiwa dalam setting tertentu dengan kacamata peneliti sendiri. Penggunaan pendekatan ini dimulai dengan sikap diam, ditunjukkan untuk menelaah apa yang sedang dipelajari. Cara fenomenolgi menekankan berbagai aspek subjektif dari perilaku manusia, selanjutnya peneliti berusaha memahami bagaimana subjek memberi arti terhadap peristiwa-peristiwa yang terjadi di sekitar kehidupannya. Peneliti percaya bahwa bagaimana cara manusia untuk menginterpretasikan pengalamannya lewat interaksi dengan orang lain (Salim \& Syahrum, 2012, p. 35).

Dengan menggunakan pendekatan penelitian kualitatif ini maka semua yang ada kaitannya dengan peran supervisi akademik kepala madrasah yang menyangkut unsurunsur supervisi akademik, teknik supervisi akademik, dan tindak lanjut supervisi akademik yang dilakukan kepala madrasah untuk dapat meningkatkan kinerja guru di MTs Darul Ulum Rasau ini dapat diuraikan secara jelas dan mendalam.

Penelitian ini dilaksanakan di MTs Darul Ulum Rasau. Sumber data dalam penelitian ini adalah kepala MTs Darul Ulum, wakil kepala madrasah bidang kurikulum, dan guru bidang studi. Pada penelitian ini peneliti akan menggunakan beberapa metode pengumpulan data sebagai berikut: observasi, wawancara, dokumentasi. Untuk mendapatkan data yang valid kemudian dilakukanlah crosscheck data menggunakan teknik triangulasi sumber data. Teknik analisa data dengan analisis induktif. Dalam penelitian ini setelah pengumpulan data maka kegiatan analisis dilakukan dengan mengikuti pola interaksi antara yaitu reduksi data, display data, dan verifikasi (Sugiyono, 2010, 32).

\section{Hasil dan Pembahasan}

Dengan mengeksplorasi pandangan para ahli seperti Glickman (1981), Daresh (1989), dan sergiovani (1987) seperti yang di kutip oleh M Shulhan (2012), yang mendefinisikan bahwa supervisi akademik merupakan "serangkaian kegiatan, membantu dan membimbing guru dalam mengembangkan kemampuannya mengelola proses pembelajaran demi mencapai tujuan pembelajaran."

Pada tahap pertemuan awal, ketika sudah diperiksa / diberi penilaian tentang perangkat pembelajaran yang sudah disiapkan oleh guru, maka langkah selanjutnya yang harus dilakukan kepala sekolah yaitu, menentukan guru yang akan di supervisi dan membuat jadwal pelaksanaan supervisi. Menurut Asep Encu dan Momon Sudarma (2020) 
"beberapa hal dalam perencanaan ini bisa didelegasikan kepada pembantu atau wakil kepala madrasah bidang kurikulum, seperti penjadwalan dan menentukan guru yang akan disupervisi." (Asep Encu \&Momon Sudarma, 2020)

Beberapa prinsip perencanaan menurut Cicih (2011) yang perlu diperhatikan dalam menyusun program supervisi, antara lain:

a. Perencanaan harus Kooperatif

Supervisi dalam pendidikan bukanlah karya pribadi supervisor, akan tetapi merupakan suatu karya bersama. Sehingga semua pihak yang memiliki kepentingan, harus selalu diikut sertakan dalam perencanaan supervisi.

b. Perencanaan harus Kreatif

Tuntutan kreatifitas menyita waktu yang cukup lama, usaha keterampilan dan kecerdasan seorang supervisor menjadi modal yang sangat dibutuhkan. Supervisor dapat mendasarkan rencananya pada pengetahuan dan pengalamannya sendiri dan atau pada pengetahuan rekan sejawatnya

c. Perencanaan harus Komprehensif

Kesulitan dalam merumuskan semua tujuan supervisi tidak menjadi hambatan. Karena pada dasarnya tujuan-tujuan supervisi merupakan satu kesatuan yang selaras dengan tujuan pendidikan atau dengan tujuan supervisi.

d. Perencanaan hrus Fleksibel

Rencana program supervisi yang baik, harus fleksibel dan mengandung kemungkinan adanya perubahan jika memang diperlukan. Para supervisor harus waspada setiap saat dalam keadaan dan kondisi apapun, karena permasalahan yang kompleks akan mempengaruhi situasi pendidikan dan program supervisi.

e. Perencanaan harus Bersinambung

Perencanaan dalam supervisi harus berkesinambungan dengan mengembangkan rencana-rencana tentatif yang bersifat percobaan, serta memperluas dan merevisi rencana-rencana itu jika memang diperlukan, karena situasi baru menimbulkan rencana-rencana baru atau menuntut penyesuaian dalam rencana-rencanayang disususn terdahulu.

Supervisi merupakan aktivitas pembinaan yang dilakukan oleh pimpinan sekolah yang terencana untuk dapat membantu para guru dan pegawai sekolah menjalankan tugas dan tanggung jawab dalam kerja secara efektif. Bantuan yang diberikan dalam pengembangan sumber daya guru dapat berupa bimbingan, dorongan, dan kesempatan 
untuk menumbuhkan kecakapan dan keahlian para guru. Pemberian layanan dan bantuan dalam meningkatkan kualitas guru berimplikasi terhadap meningkatnya kualitas belajar siswa mulai dari perencanaan pembelajaran sampai melakukan refleksi (Purwanto, 2019).

Supervisi pendidikan pada madrasah dilakukan oleh pihak-pihak yang tidak begitu berbeda dengan supervisi pada sekolah umum atau kejuruan. Supervisi pendidikan dilaksanakan oleh kemeterian agama di tingkat pusat, tingkat daerah, tingkat kecamatan, dan kepala madrasah masing-masing. Kepala madrasah kedudukannya sama dengan kepala sekolah umum, mulai dari tingkat dasar sampai dengan atas. Pelaksanaan supervisi diarahkan pada pembinaan para guru dan karyawan serta pada upaya peningkatan wawasan guru dalam pengembangan proses pembelajaran. Sementara dari sisi administrasi dilakukan berbagai pembinaan personal madrasah untuk mengelola administrasi pendidikan guna mendukung terwujudnya tujuan pendidikan. Dengan demikian, para pihak yang terkait dalam supervisi pendidikan di madrasah senantiasa bekerja sama dalam mengelola lembaganya demi kemajuan (Herabudin, 2013).

Adapun berkaitan dengan tanggung jawab supervisor dalam pendidikan dapat melaksanakan program-program supervisi terhadap terjadinya perubahan dalam kegiatan pengajaran, perubahan-perubahan tersebut dapat dilakukan dengan berbagai macam pendekatan dan berbagai usaha inovasi dalam pengembangan kurikulum serta kegiatan pendidikan dan pelatihan dalam jabatan untuk guru. Sesuai dengan tanggung jawab dalam melakukan tugasnya, maka supervisor mempunyai wewenang tertentu sesuai dengan tugas yang dilaksanakan. Wewenang supervisor adalah melaksanakan koreksi, memperbaiki dan membina proses belajar mengajar bersama guru, sehingga proses itu mencapai hasil yang maksimal (Suryani, 2015).

Kepala Sekolah adalah guru yang diberi tugas tambahan untuk mengelola dan memimpin keseluruhan proses dan substansi manajemen pendidikan di sekolah, dengan ditopang sejumlah kompetensi yang seharusnya dimiliki seorang kepala sekolah sebagaimana dinyatakan dalam Peraturan Menteri Pendidikan Nasional Nomor 13 Tahun 2007 tentang Standar Kualifikasi Akademik dan Kompetensi Kepala Sekolah mencakup (1) kompetensi kepribadian; (2) kompetensi manajerial; (3) kompetensi kewirausahaan; (4) kompetensi supervisi; dan (5) kompetensi sosial (Kristiawan, et al, 2019) (Jr. \& Hoover, 2010).

Kepala sekolah/madrasah adalah pemimpin pada suatu lembaga satuan pendidikan (Islam). Tanpa kehadiran kepala sekolah proses pendidikan termasuk 
pembelajaran tidak akan berjalan dengan efektif. Kepala sekolah/madrasah diangkat melalui prosedur serta persyaratan tertentu semisal dapat dipilih secara langsung, ditetapkan oleh yayasan, atau ditetapkan oleh pemerintah yang mana kepala sekolah bertanggung jawab atas tercapainya tujuan pendidikan melalui upaya peningkatan profesionalisme tenaga kependidikan yang mengimplikasikan meningkatnya prestasi belajar peserta didik.

Kepala sekolah yang profesional akan berfikir untuk membuat perubahan dalam meningkatkan kualitas pendidikan yang berimplikasi juga pada mutu (input, proses, dan out put) (Rodliyah, 2014).

Berdasarkan wawancara dengan kepala MTs Darul Ulum Rasau diperoleh data "bahwa dalam pelaksanaan supervisi akademik dilakukan dengan cara membuat perencanaan/kontrak terlebih dahulu, selanjutnya melaksanakan, kemudian menindaklanjuti/penguatan dari pelaksanaan supervisi tersebut”.

Hal tersebut dipertegas dengan wawancara guru-guru. Mereka mengatakan bahwa sebelum dilaksanakan supervisi, mereka telah mendapatkan surat keputusan tentang kegiatan supervisi akademik yang dilampirkan jadwal pelaksanaan dari kepala sekolah. Hal tersebut dilakukan agar guru-guru dapat mempersiapkan diri dan mengetahui kapan jadwal supervisi dilaksanakan. Bagi guru yang belum melengkapi perangkat pembelajaran, diberi waktu satu minggu oleh kepala madrasah untuk melengkapi perangkat pembelajaran tersebut sebelum pelaksanaan supervisi dilakukan.

Berdasarkan hasil wawancara dengan wakil kepala madrasah bidang kurikulum sebelum jadwal pelaksanaan supervisi dijadwalkan, di mana kegiatan pembelajaran dilaksanakan secara daring (online) adalah dengan cara bergabung ke dalam grup WA pembelajaran kelas untuk mengamati jalannya proses pembelajaran jarak jauh (PJJ). Kepala madrasah dalam melaksanakan supervisi menggunakan pendekatan humanistik bukan dalam rangka mencari-cari kesalahan, tetapi sungguh-sungguh membantu guru untuk dapat bekerja yang lebih bagus dan terarah dalam melaksakan tugasnya.

Sebelum kunjungan kelas secara virtual kepala madrasah biasanya melakukan pembicaraan individual dan kelompok dengan guru-guru yang akan disupervisi. Diskusi tersebut membahas tentang masalah-masalah yang dihadapi guru yang berkaitan dengan pelaksanaan belajar mengajar. Hal ini seperti yang dituturkan oleh guru Agama (Intan Syafitri), bahwa: "Teknik supervisi yang dilakukan kepala madrasah adalah dengan kunjungan kelas virtual. Hal ini dilakukan agar mendapatkan gambaran sesungguhnya 
bagaimana pelaksanaan PJJ tersebut. Di samping teknik kunjungan kelas virtual, teknik individual antara guru dengan supervisor juga sangat membantu guru dalam memperbaiki sistem mengajar yang lebih baik. Tinggi rendahnya kemampuan professional guru dalam pelaksanaan pembelajaran juga ditentukan pada kemampuan kepala madrasah dalam membina guru-guru tersebut. Oleh karena itu, kepala madrasah harus melaksanakan supervisi terhadap guru-guru untuk mengetahui tingkat profesionalnya meningkat atau menurun, malas atau tidak, disiplin atau tidak dan sebagainya."

Selanjutnya, guru Bahasa Inggris (Mr. Hendrawan) menuturkan jelaskan, bahwa: "Dalam menyusun program supervisi pendidikan kami selalu mengadakan musyawarah dengan semua guru dan bekerja sama dengan penuh disiplin, rasa tanggung jawab serta selalu menjaga keharmonisan antara guru dan atasan". Adapun hambatan supervisi akademik yang dihadapi dalam pelaksanaan supervisi pendidikan di sekolah, antara lain: padatnya jadwal kegiatan yang harus dilakukan kepala madrasah dalam waktu yang bersamaan, dan keterbatasan dana operasional sekolah untuk pembinaan guru.

Dalam hal padatnya jadwal kepala madrasah selama ini, biasanya tugas pelaksanaan supervisi akan diberikan kepada wakil kepala madrasah atau guru senior. Hal ini sesuai dengan apa yang dikatakan kapala madrasah, "Biasanya jika ada tugas keluar, sementara jadwal supervisi sudah disusun dengan bagus, maka biasanya saya akan mendelegasikan tugas kepada wakil kepala madrasah atau guru senior. Hal ini juga sebagai upaya kaderisasi dan pembagian tugas kepada staff'. Untuk itu mengatasi keterbatasan anggaran supervisi, kepala madrasah meminta bantuan kepada komite madrasah agar memfasilitasi kegiatan supervisi secara berkala. Hambatan lain yang dihadapi dalam pelaksanaan supervisi di masa pandemi ini adalah kemampuan penguasaan IT beberapa guru senior. Sehingga hal ini sedikit akan mengganggu proses pelaksanaan supervisi yang dilakukan secara online.

Dari hasil wawancara beberapa guru yang sudah tua "Selama PJJ ini, kami guruguru yang sudah tua, sering mengalami kendala terkait penggunaan sarana IT. Tapi Alhamdulillah ... Bapak kepala madrasah menyiapkan beberapa staff IT yang siap membantu kami menyelesaikan masalah komunikasi", tutur guru senior. Permasalahan lain yang dialami dari sisi pendidik adalah kemampuan pendidik dalam hal penguasaan metode pembelajaran. Seharusnya, dalam proses pembelajaran yang dilakukan secara daring (online) guru menguasai dan mampu menerapkan metode pembelajaran yang berbeda dengan metode pembelajaran saat tatap muka. Hal ini menjadi masalah tersendiri ketika 
guru masih mengajar dengan menggunakan metode konvensional seperti saat mengajar tatap muka. Dari hasil supervisi pendidikan yang telah dilaksanakan pada masa pandemic Covid-19 (semester gasal tahun pelajaran 2020/2021) ini, kepala madrasah mengajak wakil kepala madrasah dan beberapa guru untuk mencari solusi dan tindak lanjut dari hasil supervisi tersebut.

Tindak lanjut yang telah dilakukan oleh kepala madrasah terkait temuan hasil supervisi di antaranya adalah:

1. Membagi peran dan tugas sebagai supervisor kepada wakil kepala madrasah dan guru senior.

2. Berkoordinasi dengan komite madrasah untuk memenuhi kebutuhan dana dalam pelaksanaan supervisi akademik.

3. Memfasilitasi beberapa guru untuk mengikuti pelatihan pembelajaran secara online melalui aplikasi Zenius.

4. Melengkapi sarana IT untuk mempermudah guru dalam mengembangkan kemampuan serta menunjang proses pelaksanaan PJJ.

\section{Kesimpulan}

Supervisi pendidikan di MTs Darul Ulum Rasau dilaksanakan melalui beberapa tahapan, yaitu: perencanaan, pelaksanaan, dan tindak lanjut (evaluasi). Supervisi akademik dilakukan oleh kepala madrasah dan dibantu oleh wakil kepala madrasah dan guru senior. Hal yang disupervisi meliputi: supervisi administrasi dan akademis. Supervisi administrasi dilaksanakan sebelum pelaksanaan PJJ. Supervisi akademik dilaksanakan dengan cara supervisor bergabung dalam kelas virtual atau kelas online. Hambatan yang dialami dalam pelaksanaan supervise antara lain yaitu padatnya jadwal kegiatan kepala madrasah, kemampuan IT beberapa pendidik yang masih rendah, sarana dan prasarana madrasah penunjang pelaksanaan PJJ yang belum memadai.

Tindak lanjut yang dilakukan oleh kepala madrasah dalam mengatasi penguasaan metode mengajar beberapa guru adalah dengan memfasilitasi guru untuk mengikuti pelatihan secara online melalui aplikasi Zenius. Selain itu, madrasah juga menyediakan sarana yang dibutuhkan guru-guru tersebut dalam pelaksanaan PJJ berupa ketersedian computer dan gawai yang memadai.

\section{Daftar Pustaka}


Ajasan, N. U. N. 2016. Efektivitas Pelaksanaan Supervisi Akademik Oleh Kepala Sekolah Dalam Meningkatkan Kinerja Guru Di SMK Negeri 1 Meulaboh. Jurnal Administrasi Pendidikan : Program Pascasarjana Unsyiah

Asep Encu \&Momon Sudarma. 2020. Menjadi kepala Madrasah Profesional. Depok: PT. Raja Grafindo Persada

Elfidawati, E. 2020. Peningkatan Kedisiplinan dan Kualitas Pembelajaran Guru Pada Masa Pandemi Covid-19 melalui Supervisi Akademik di SD 009 Kuala Terusan Pangkalan Kerinci. Jurnal Kepemimpinan Dan Pengurusan Sekolah, 5 (2), 171179

Fathurrahman, F. 2018. Peningkatan Profesionalisme Guru Bahasa Melalui Supervisi Pengajaran Kepala Sekolah. Jurnal Reforma. https://doi.org/10.30736/rfma.v7i1.38

Himmatul Husniyah. 2021. Pengaruh Profesionalisme Guru Terhadap Peningkatan Prestasi Belajar Siswa Kelas X Di Madrasah Aliyah 02 Pondok Modern Paciran Lamongan. Jurnal Annaba STIT Muhammadiyah Paciran. Vol. 7 No. 1

Herabudin. 2013. Administrasi dan Supervisi Pendidikan. Bandung: CV. Pustaka Setia.

Kristiawan, M., Yuniarsih, Y., Fitria, H., \& Refika, N. 2019. Supervisi Pendidikan. Bandung: Alfabeta

La Ode Ismail Ahmad. 2017. Konsep Penilaian Kinerja Guru dan Faktor yang Mempengaruhinya. Jurnal Idarah, 133

Mahmud. 2011. Metode Penelitian Pendidikan. Bandung: CV. Pustaka Setia

M. Chotibuddin. 2017. Upaya Kepala Sekolah Dalam Meningkatkan Kreatifitas Guru Di Madrasah Ibtidaiyah Muhammadiyah 15 Banjarwati Paciran Lamongan. Jurnal Annaba STIT Muhammadiyah Paciran. Vol. 3 No. 1

Purwanto, M. N. 2019. Administrasi dan Supervisi Pendidikan. Bandung: PT Remaja Rosdakarya

Raluca David et. al. 2020, April. Education during the COVID-19 Crisis Creative Commons Attribution 4.0. International License

Rodliyah, S. 2014. Supervisi Pendidikan dan Pembelajaran. Jember: STAIN Jember Press Sabandi, A. 2013. Supervisi Pendidikan Untuk Pengembangan Profesionalitas Guru Berkelanjutan. Jurnal Ilmiah Ilmu Pendidikan

Salim, S., \& Syahrum, S. (2012). Metodologi Penelitian Kualitatif. Bandung: Citapustaka Media 
Subhan Adi Santoso, Ali Mustofa, 2019. Ilmu Pendidikan Islam Era Industri 4.0. Malang: Media Sutra Tiga

Subhan Adi Santoso, Maulidyah Amalina Rizqi 2020. Kinerja Pengawas Sekolah, Kepala Sekolah, dan Guru pada Pendidikan. Yogyakarta: Deepublish

Subhan Adi Santoso, 2020. Media Pembelajaran Pendidikan Agama Islam Era Industri 4.0. Yogyakarta: Deepublish

Subhan Adi Santoso, M. Chotibuddin, 2020. Pembelajaran Blended Learning Masa Pandemi. Pasuruan: Qiara Media

Subhan Adi Santoso, Himmatul Husniyah, 2021. Pendidikan Agama Islam Berbasis IT. Yogyakarta: Zahir Publishing

Subhan Adi Santoso, 2017. Pengaruh Kompetensi Pedagogik Guru Terhadap Prestasi Belajar Siswa Kelas XI Mata Pelajaran PAI Di SMKN 13 Malang. Jurnal Tamaddun: Vol. 18 No. 2. 2017

Subhan Adi Santoso, 2021. Peran Kepala Sekolah Dalam Meningkatkan Mutu Pendidikan Agama Islam Di Madrasah Aliyah Muhammadiyah 02 Paciran Lamongan. Jurnal Annaba: Vol. 7 No. 2. 2017

Sugiyono, P. D. (2010). Metode Penelitian Kuantitatif dan Kualitatif. In Bandung: CV Alfabeta. Bandung: CV. Alfabeta

Sugiyono. (2011). Metodologi Penelitian Kuantitatif Kualitatif dan R\&D. Alpabeta, Bandung

Suryani, C. (2015). Implementasi Supervisi Pendidikan dalam Meningkatkan Proses Pembelajaran di MIN Sukadamai Kota Banda Aceh. Jurnal Ilmiah Didaktika: Media Ilmiah Pendidikan Dan Pengajaran, 16(1), 23-42.05202017950 
1. Musonip Saputro, 2. M Fathoni,

3. Minnah El Widdah, 4. Suryawahyuni Latief

86 Volume 8 No. 1, 1 Maret 2022 